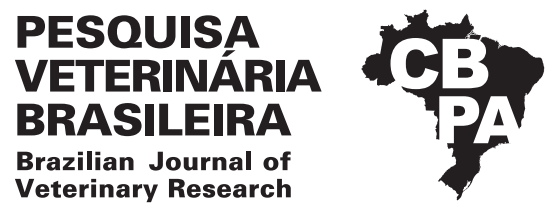

Pesq. Vet. Bras. 39(8):564-572, August 2019 DOI: $10.1590 / 1678-5150-P V B-6215$

Original Article

ISSN 0100-736X (Print)

ISSN 1678-5150 (Online)

\title{
Hypomagnesemia in dairy cattle in Uruguay ${ }^{1}$
}

\author{
Benjamín Doncel ${ }^{2,3}$, Alsiane Capelesso $^{4}$, Federico Giannitti ${ }^{3}$, \\ Cecilia Cajarville ${ }^{4}$, Melissa Macías-Rioseco ${ }^{3}$, Caroline Silveira ${ }^{3}$, Ricardo A. Costa ${ }^{3}$ \\ and Franklin Riet-Correa ${ }^{3 *}$
}

\begin{abstract}
Doncel B., Capalesso A., Giannitti F., Cajarville C., Macías-Rioseco M., Silveira C., Costa R. A. \& Riet-Correa F. 2019. Hypomagnesemia in dairy cattle in Uruguay. Pesquisa Veterinária Brasileira 39(8):564-572. Instituto Nacional de Investigación Agropecuaria, Plataforma de Investigación en Salud Animal, Estación Experimental INIA La Estanzuela, Ruta 50 km 11, 39173, Colonia, Uruguay. E-mail: frcorrea@inia.org.uy

An outbreak of hypomagnesemia is reported in Holstein dairy cattle grazing lush oat (Avena sativa) pasture in Uruguay. Nine of 270 (3.3\%) cows died in May-July (autumn-winter) 2017. These nine cows were from 2 to 9-years-old (1st-6th lactation), with 22 to 194 days of lactation and 15.8 to $31.4 \mathrm{~L}$ of daily milk production. Two cows with acute sialorrhea, muscle spasms, lateral recumbency, weakness, opisthotonos, and coma, were euthanized and necropsied. No significant macroscopic or histological lesions were found. One untreated clinically-affected cow and eight out of 14 clinically healthy cows of the same group under similar management and production conditions had low serum levels of $\mathrm{Mg}$ (lower than $0.7 \mathrm{mmol} / \mathrm{L})$. Secondarily, both clinically affected cows and six out of 14 healthy cows had low serum Ca levels. The $\mathrm{K} /(\mathrm{Ca}+\mathrm{Mg})$ ratio of two oat forages, corn silage, and ration was $5.10,7.73,2.45$, and 0.85 , respectively. $\mathrm{A} \mathrm{K} /(\mathrm{Ca}+\mathrm{Mg})$ ratio lower than 2.2 represents a risk for hypomagnesemia. The difference between the contribution-requirement of minerals in the diet was established and a daily deficiency of $\mathrm{Mg}(-0.36 \mathrm{~g} /$ day $), \mathrm{Na}(-25.2 \mathrm{~g} / \mathrm{day})$ and Ca $(-9.27 \mathrm{~g} /$ day) was found, while K $(184.42 \mathrm{~g} /$ day) and P $(12.81 \mathrm{~g} /$ day) were in excess. The diet was reformulated to correct the deficiencies and the disease was controlled by the daily administration of $80 \mathrm{~g}$ of magnesium oxide, $80 \mathrm{~g}$ of calcium carbonate and $30 \mathrm{~g}$ sodium chloride per cow. It is concluded that hypomagnesemia is a cause of mortality in dairy cattle in Uruguay, and that the condition can be prevented by appropriate diet formulation.
\end{abstract}

INDEX TERMS: Grass tetany, grazing dairy cows, hypocalcemia, hypomagnesemia, lush oat pasture, dairy cattle, Uruguay, cattle, pathology.

RESUMO.- [Hipomagnesemia em bovinos leiteiros no Uruguai.] Descreve-se um surto de hipomagnesemia em bovinos leiteiros da raça Holandês com alimentação a base de pastagens de aveia (Avena sativa) em crescimento no Uruguai, nos meses de maio a julho (outono-inverno) de 2017. De um rebanho de 270 vacas em ordenha, nove $(3,3 \%)$ morreram. As nove vacas tinham entre dois e nove anos,

\footnotetext{
${ }^{1}$ Received on November 22, 2018.

Accepted for publication on March 22, 2019.

${ }^{2}$ Universidad Nacional de Colombia, Sede Bogotá, Facultad de Medicina Veterinaria y de Zootecnia, Laboratorio de Patología Veterinaria, Carrera 30 N 45-03, Edificio 502, Código postal 11001, Bogotá, Colombia.

${ }^{3}$ Instituto Nacional de Investigación Agropecuaria (INIA), Plataforma de Salud Animal, Estación Experimental INIA La Estanzuela, Ruta $50 \mathrm{Km}$ 11, 39173, Colonia, Uruguay. *Corresponding author: frcorrea@inia.org.uy

${ }^{4}$ Departamento de Nutrición, Instituto de Producción Animal (IPAV), Facultad de Veterinaria, Av. 18 de Julio 11200, 1824-1850 Montevideo, Uruguay.
}

estavam entre a primeira e a sexta lactação e a produção diária era de 15,8 a 31,4 litros de leite. Duas vacas que apresentaram sialorreia, espasmos musculares, decúbito lateral, debilidade, opistótono e posteriormente, estado comatoso foram eutanasiadas e necropsiadas. Não foram observadas lesões macroscópicas ou histológicas significantes. Uma vaca com sinais clínicos, não tratada, e oito de 14 vacas sem sinais clínicos, do mesmo rebanho, apresentaram baixos níveis séricos de $\mathrm{Mg}$ (menos de 0,7mmol/L). Adicionalmente, as duas vacas com sinais clínicos e seis das 14 vacas sem sinais clínicos apresentaram baixos níveis de Ca sérico. A relação do risco tetanizante $\mathrm{K} /(\mathrm{Ca}+\mathrm{Mg})$ de duas pastagens de aveia, silagem de milho e ração concentrada foi estimada em $5 ; 10 ; 7,73 ; 2,15$ e 0,85 , respectivamente. Uma relação $\mathrm{K} /(\mathrm{Ca}+\mathrm{Mg})$ maior de 2,2 é um indicador do potencial tetanizante da forragem, A diferença entre o aporte e os requerimentos dos minerais foi estabelecida constatando-se deficiência diária de 
Mg (-0,36g/dia), Na (-25,2g/dia) e Ca $(-9,27 \mathrm{~g} /$ dia $) .0$ potássio (K) $(184,42 \mathrm{~g} /$ dia $)$ e o fósforo (P) $(12,81 \mathrm{~g} /$ dia $)$ estavam em excesso. A dieta foi reformulada para corrigir as deficiências e a doença foi controlada mediante a administração diária de $80 \mathrm{~g}$ de $\mathrm{MgO}, 80 \mathrm{~g}$ de $\mathrm{CaCO}_{3}$ e $30 \mathrm{~g}$ de $\mathrm{NaCl}$ por vaca. Conclui-se que a hipomagnesemia é uma doença de importância crescente em gado leiteiro no Uruguai e que deve ser prevenida mediante a formulação correta da dieta.

TERMOS DE INDEXACAO: Vacas leiteiras em pastejo, pastagens de aveia, hipocalcemia, hipomagnesemia, Uruguai, patologia.

\section{INTRODUCTION}

Hypomagnesemia is a disorder of ruminants biochemically characterized by low serum magnesium (Mg) (Grunes et al. 1970, Crawford et al. 1998). It most commonly affects grazing cattle, which may be asymptomatic or develop clinical signs, or die abruptly sometimes leading to high mortality rates (Grunes et al. 1970, Meyer 1977, Smith \& Edwards 1988, Constable et al. 2017, Zelal 2017). Mg is an essential cofactor in numerous enzymatic processes of the main metabolic pathways (Martín-Tereso \& Martens 2014), an important intracellular second messenger (Li et al. 2011) and participates in osteogenic differentiation (Zheng et al. 2016), neurotransmission (Möykkynen et al. 2001) and muscle function (Goff 1999).

$\mathrm{Mg}$ is distributed mainly in bones (60-70\%) (Rayssiguier \& Larvor 1978), approximately $30 \%$ is intracellular and only $1 \%$ is in the extracellular space, including the blood (Storry \& Rook 1962, Goff 1999). Blood levels of Mg depend on the balance between absorption and excretion rates (Martens et al. 2018) and are easily altered in cows because $\mathrm{Mg}$ in bones is not readily available (Storry \& Rook 1962) and only 30\% can be mobilized from this site (Alfrey \& Miller 1973). In cattle, $\mathrm{Mg}$ is excreted in milk (4.1-4.9mmol/L) (Cerbulis \& Farrell Junior 1976), urine (0.017-0.17 mmol/day) (Kemp et al. 1961) and digestive secretions $(0.00017 \mathrm{mmol} / \mathrm{kg}$ body weight) (Schonewille et al. 2008). Additionally, in pregnant cattle, Mg requirements in developing fetuses during late gestation are $0.014 \mathrm{mmol} /$ day (House \& Bell 1993). Normal values of Mg in plasma for dairy cattle range between 0.7 and 1.2 according to Constable et al. (2017) or between 0.9-1.2 according to Martens et al. (2018). In the cerebrospinal fluid of cows, the $\mathrm{Mg}$ ranges from 0.62 to $0.81 \mathrm{mmol} / \mathrm{L}$ (McCoy et al. 2001). The concentration of $\mathrm{Mg}$ in vitreous humor is 0.84 to $0.90 \mathrm{mmol} / \mathrm{L}$ of $\mathrm{Mg}$, and in the aqueous humor ranges from 0.73 to $0.79 \mathrm{mmol} / \mathrm{L}$ (McCoy et al. 2001). Mg concentration in vitreous humor is stable for up to approximately $48 \mathrm{~h}$ postmortem, which can be used in the postmortem diagnosis of hypomagnesemia (McCoy 2004). In the presence of mineral disorders, it is important to evaluate not only Mg but also Ca levels, because in general both minerals are low in blood (Reinhardt et al. 2011). In cases of Mg deficiency, low Ca values are attributed to hypomagnesemia (Van Mosel et al. 1991).

Hypomagnesemia affects cattle, sheep and goats, but cattle are more susceptible (Grunes et al. 1970). The annual morbidity and mortality registered in 120 dairy cattle farms in southwestern Victoria, Australia, was $2.1 \%$ and $0.53 \%$, respectively (Harris et al. 1983). In England and Wales, a $7.8 \%$ mortality rate in in dairy cattle was recorded in 2004 (Watson et al. 2008), whereas in the province of Buenos
Aires, Argentina, 3\% and 4\% mortality rates were registered in beef herds over periods of 15 and 20 years, respectively (Cseh \& Crenovich 1996, Cantón et al. 2014). In Uruguay, outbreaks of hypomagnesemia have been recorded in beef cattle under stress caused by weaning, transportation and prolonged confinement without access to food or water (Dutra 2009, 2010).

Primary hypomagnesemia occurs when Mg deficit in the diet is less than $1.3 \mathrm{~g} / \mathrm{kg}$ dry matter (DM) (Ram et al. 1998), whereas secondary hypomagnesemia is due to low ruminal absorption of $\mathrm{Mg}$ despite adequate dietary concentration (Care et al. 1984). The rumen is the primary absorption site for Mg (Martens et al. 2018). The solubility and absorption of $\mathrm{Mg}$ decrease when the ruminal $\mathrm{pH}$ is less than 6.5 (Goff 2008). Potassium (K) ions interfere with ruminal absorption of $\mathrm{Mg}$ because it raises the apical membrane potential of the ruminal epithelial cells (Martens \& Blume 1986, Martens \& Schweigel 2000), increases the ruminal $\mathrm{pH}$ and causes ruminal and metabolic alkalosis (Fisher et al. 1994, Rérat et al. 2009). Therefore, high content of $\mathrm{K}$ in the diet affect the absorption of $\mathrm{Mg}$ in ruminants. Particularly when the $\mathrm{K} /(\mathrm{Ca}+\mathrm{Mg})$ ratio is greater than 2.2 , the diet is potentially tetanizing (Kemp \& t'Hart 1957). Similar effects occur with phosphorous (P) and nitrogen $(\mathrm{N})$ that also increase the ruminal $\mathrm{pH}$ and may form insoluble hydroxides with dietary Mg (Gabel \& Martens 1986, Reinhardt et al. 1988). In contrast, fatty acids, such as linolenic, linoleic and palmitic, form insoluble salts with Mg decreasing its absorption in the rumen (Goff 2006). Transaconitate is a forage metabolite that chelates $\mathrm{Mg}$ and can contribute to its deficiency (Cook et al. 1994). Diets deficient in sodium (Na) and energy also negatively affect the active ruminal absorption of Mg (Martens 1985, Martens \& Blume 1986).

$\mathrm{Mg}$ requirements increase during the end of gestation and the beginning of lactation because of the flow of $\mathrm{Mg}$ to the fetus and colostrum or milk (Cerbulis \& Farrell Junior 1976, House \& Bell 1993). Hypomagnesemia is more frequent in adult multiparous cows (Reinhardt et al. 2011), because $\mathrm{Mg}$ absorption and resorption in those animals are reduced (Van Mosel et al. 1991). Calves can be affected when consume only milk or milk replacers deficient in Mg (Naik et al. 2010, Constable et al. 2017).

Hypomagnesemia is also influenced by body condition. Cows with body condition greater than 3.75 (1 to 5 scale) increase lipolysis for energy supply (Rayssiguier 1977, Contreras et al. 2016, Alharthi et al. 2018). During lipolysis, catecholamines and adrenocorticotropic hormones stimulate Mg uptake by adipocytes (Elliott \& Rizack 1974), since Mg is required by adenylate cyclase, ATPases, and lipases during this process (Rude 1998).

Hypomagnesemia is favored by environmental factors (Larvor 1976). In Argentina, winter and spring are seasons of higher risk for hypomagnesemia in grazing cattle (Cseh \& Crenovich 1996). In general, the annual winter grasses (oat, wheat and ryegrass) are rich in $\mathrm{K}$ and deficient in $\mathrm{Mg}$, therefore they pose a greater risk for grass tetany (Metson et al. 1966). The risk increases with fast growing forage, especially in the middle of autumn and early winter (Brizuela \& Cseh 2003). Therefore, hypomagnesemia commonly occurs in cattle grazing perennial forages of autumn-winter growth (Metson et al. 1966) or lush annual forages such as ryegrass (Lolium sp.), wheat (Bohman et al. 1983), oat, and barley (Brizuela \& Cseh 
2003). These forages are rich in non-protein $\mathrm{N}$ that favor increased levels of ammonia and the ammonium ion, which precipitate Mg (Gabel \& Martens 1986, Flores et al. 2014). The shortage of non-structural carbohydrates of these forages (Bohman et al. 1983, Chatterton et al. 1989, Chatterton et al. 2006, Cajarville et al. 2015) also contributes to the deficit of Mg since they facilitate Mg absorption (Giduck \& Fontenot 1987).

Annual winter growing grasses also have high water content that increases the transit speed of the forage in the gastrointestinal tract and thus reduces the absorption of $\mathrm{Mg}$ in the rumen (Grunes et al. 1970, Maylan et al. 1976). Pasture management practices may affect the availability of Mg. For example, fumigation against broadleaf weeds reduces legumes with higher levels of $\mathrm{Mg}$, such as clover and alfalfa (Jones 1963). In addition, the increase in animal density together with the excessive use of fertilizers containing $\mathrm{N}$ and $\mathrm{K}$ (Macdonald et al. 2017) reduces the availability of Mg to the plant and, consequently, the animal (Grunes et al. 1970, Fox \& Piekielek 1984, Elliott 2008). Although hypomagnesemia is more common in winter and spring, it can also occur in autumn and summer (Allcroft \& Burns 1968, Larvor 1976). The disease is exacerbated by stress conditions such as heat, overcrowding, transportation, changes in diet or starvation (Larvor 1976, Rayssiguier 1977).

Hypomagnesemia can be subclinical, with plasma Mg between 0.41-0.82 (Constable et al. 2017) or 0.7-0.8mmol/L (Martens at al. 2018), and clinical, with concentration on average of $0.21 \mathrm{mmol} / \mathrm{L}$ (Constable et al. 2017). Clinical disease has three forms of presentation: acute, subacute and chronic (Smith \& Edwards 1988). Acute illness is characterized by violent movements of the limbs, usually there is foam at the mouth and nostrils; sudden death can occur and is often the sole manifestation of the disease. Cows with subacute course show spasms in the face with continuous involuntary muscle movements. Some animals show nervousness, aggressiveness, teeth grinding, salivation or strong vocalization. Blindness, muscle spasms, excitability, rigid gait, dysmetria, and ataxia can be observed. Later they can remain in sternal or lateral recumbency, with rigid limbs, paddling movements or opisthotonos (Allcroft \& Burns 1968, Martens \& Schweigel 2000, McCoy et al. 2001, D’Angelo et al. 2015). Weight loss and decreased production are hallmarks of the chronic form of hypomagnesemia (Reinhardt et al. 1988, Smith \& Edwards 1988).

Hypomagnesemia can be prevented by assessing the tetanizing potential of the forage before grazing (Kemp \& t'Hart 1957, Brizuela \& Cseh 2003). To prevent hypomagnesemia, it is necessary to supplement $\mathrm{Mg}$ in the diet by administering 0.35 to $0.40 \% \mathrm{Mg}$ in the total dry ration from a source with adequate bioavailability (Goff 1999, Martens \& Schweigel 2000, NRC 2001). Diets should be adjusted according to production requirements. Unnecessary management that imposes stress to the animals should be reduced, animals should not be transported in the last 6 weeks of gestation, and abrupt changes in diet should be avoided (Elliott 2009). Cattle consuming lush fast-growing grasses should be supplemented with $\mathrm{Mg}$. Alternatively, farmers should implement the association of grasses with leguminous plants or add an appropriate amount of legume hay, that is rich in $\mathrm{Mg}$, and provides fiber to decrease the transit speed of the forage through the digestive tract to improve ruminal Mg absorption (Smith \& Edwards 1988, Muller 2003, Constable et al. 2017). It has been suggested that subclinical hypomagnesemia in the postpartum is a heritable trait (Tsiamadis et al. 2016).

Clinical cases of hypomagnesemia can be treated by administering Mg solutions intravenously or subcutaneously. Blood levels of $\mathrm{Mg}$ are recovered by administering $200 \mathrm{ml}$ of $50 \% \mathrm{Mg}$ solution. Alternatively, 200 to $400 \mathrm{ml}$ of $25 \%$ solution of magnesium sulfate $\left(\mathrm{MgSO}_{4} 7 \mathrm{H}_{2} \mathrm{O}\right)$ can be administered subcutaneously, a maximum of 50 to $100 \mathrm{ml}$ per site of application is recommended (Goff 1999). Clinical cases can be reduced by moving the herd or affected animals off the paddock and supplementing Mg in the diet (Sánchez 2000).

The objective of this work is to describe an outbreak of hypomagnesemia in dairy cattle in Uruguay and make recommendations for the prophylaxis and control of the disease.

\section{MATERIALS AND METHODS}

Nine lactating cows died acutely within 59 days (May 13-July 16, 2017 ) in a herd of 270 Holstein cows. Two cows with acute clinical signs that were in permanent recumbency and moribund were subjected to clinical examination, followed by euthanasia and necropsy. Tissue samples were collected and fixed in $10 \%$ buffered formalin, embedded in paraffin, cut into $4-5 \mu \mathrm{m}$ thick sections and stained with hematoxylin and eosin (HE) for microscopic examination.

Blood samples were collected from the two clinically affected cows and from 14 clinically healthy cows in the same herd under similar management and production conditions. The blood serum was separated and submitted to the clinical pathology section of the Direction of Veterinary Laboratories (Dirección de Laboratorios Veterinarios) (DILAVE) for determination of serum Ca by o-cresolphthalein complexone and 8-hydroxyquinoline procedures (Bazydlo et al. 2014). Total blood $P$ was determined by the ammonium molybdate method measured at $340 \mathrm{~nm}$ wave-length, and $\mathrm{Mg}$ concentration was assessed by the xylidyl blue reaction (Wiener lab ${ }^{\circledR}$, Argentina) (Baginski et al. 1975, Bazydlo et al. 2014).

Tissue samples from lung, kidney, liver and cerebrospinal fluid (CSF) were subjected to microbiological culture on blood, chocolate and McConkey agars. The CSF was cultured in selective medium for Listeria spp. and incubated in a microaerophilic atmosphere for $48 \mathrm{~h}$ at $37^{\circ} \mathrm{C}$ (Van Netten et al. 1989).

Oat grass samples (including 10 subsamples from each of two pastures A and B) were obtained for mineral evaluation. Pasture A was being grazed by the ill animals, and pasture B had previously been grazed by the same herd. Additionally, samples of the concentrate ration, corn silage and water were collected. These samples were assessed for $\mathrm{P}, \mathrm{Ca}, \mathrm{Mg}$ and $\mathrm{K}$ by atomic absorption, $\mathrm{Mg}$ and $\mathrm{Ca}$ by atomic emission, $\mathrm{K}$ by wet digestion and $\mathrm{P}$ by colorimetry at the Soil, Plant and Water Laboratories (INIA 2017) of the National Institute of Agricultural Research (INIA) La Estanzuela) (Jackson 1964). The $P$ available in the water was determined by the digestion technique with ascorbic acid and colorimetry at the same laboratory.

Intake of DM was estimated based on the data obtained in the farm on diet and milk production, according to the NRC (2001). The mineral requirements ( $\mathrm{P}, \mathrm{Ca}, \mathrm{Mg}, \mathrm{K}$ and $\mathrm{Na}$ ) of the cows and the water consumption were estimated from the NRC (2001). To calculate the mineral contributions, the ingested quantities of oat grass, corn silage, ration, water and the mineral supplement were considered. The difference contribution-requirements of the diet was calculated, and a correction of the deficiencies was formulated. 


\section{RESULTS}

The outbreak occurred in a dairy farm located nearby Colonia Cosmopolita (latitude South $34^{\circ} 23^{\prime} 04^{\prime \prime}$, longitude West $\left.57^{\circ} 24^{\prime} 01^{\prime \prime}\right)$, in the department of Colonia, Uruguay, in autumn-winter, from May 13 to July 16, 2017. The farm had 270 lactating Holstein cows managed in a single herd. The animals were consuming lush oat pastures in two daily grazing shifts, as well as corn silage and a ration consisting of ground corn kernels, ground barley grain, soybean meal, mineral supplement and monensin.

Mortality in the study period was 3.3\%. The 9 dead cows were between 2 and 9-years of age (1st to 6th lactation), with 22 to 194 days of lactation and 15.8 to $31.4 \mathrm{~L}$ of daily milk production. Two cows were found moribund. Cow \#1131 was in right lateral recumbency and had opisthotonos, muscular spasms, profuse salivation and ruminal atony. The rectal temperature was normal $\left(35.9^{\circ} \mathrm{C}\right)$, the respiratory rate was of 80 movements per minute (tachypnea) and the heart rate of 160 beats per minute (tachycardia). Cow \#1175 was in sternal and later in lateral recumbency, with weakness, sialorrhea and comatose state.

The animals grazed growing oat pasture in two daily grazing shifts and consumed $15 \mathrm{~kg}$ of corn silage administered in the paddock, and $4 \mathrm{~kg}$ of ration/cow/day (administered in the dairy, $2 \mathrm{~kg}$ per milking shift). The daily concentrate ration per cow was composed of $2.345 \mathrm{~kg}$ of ground corn grain, $0.781 \mathrm{~kg}$ of soybean meal, $0.781 \mathrm{~kg}$ of milled grain barley, $0.09 \mathrm{~kg}$ of commercial mineral supplement, and $0.0015 \mathrm{~kg}$ of a commercial product containing $20 \%$ monensin.

Table 1 shows the data and the results of the evaluation of $\mathrm{P}, \mathrm{Ca}$ and $\mathrm{Mg}$ in the serum of two clinically-affected cows and 14 healthy cows within 42 to 132 days of lactation and milk production between 17 and 32.2L per day. Cow \#1131 with clinical signs, that had not received any medical treatment, had low serum levels of Mg and Ca. Cow \#1715 with clinical signs, had been treated with a solution of $\mathrm{Ca}$ and $\mathrm{Mg}$, and with methylene blue. In this cow, the serum Mg values were within normal parameters, but the values of $\mathrm{Ca}$ and $\mathrm{P}$ were low. The serum values of these minerals in the 14 clinically healthy untreated cows were distributed as follows: four cows had low values of Mg only, four cows had low values of $\mathrm{Mg}$ and $\mathrm{Ca}$, two cows had low values of $\mathrm{Ca}$ and $\mathrm{P}$, and four cows showed normal values of the three minerals.

The dietary values of minerals are shown in Table 2 . The tetanizing potential was calculated by the $\mathrm{K} /(\mathrm{Ca}+\mathrm{Mg})$ ratio of each component of the diet. The tetanizing potential of the oat forages (pastures A and B), corn silage and the ration were $5.10,7.73,2.45$ and 0.85 , respectively. The Ca:P ratio was 0.87 on average of components of the diet.

Table 3 shows the estimate of DM intake according to the components of the diet at the time of the visit to the farm. A daily consumption of $19.6 \mathrm{~kg}$ was estimated. Mineral concentrations in water were as follows: $\mathrm{Ca}=53.4 \mathrm{mg} / \mathrm{L}$, $\mathrm{Mg}=30.1 \mathrm{mg} / \mathrm{L}, \mathrm{K}=12.5 \mathrm{mg} / \mathrm{L}$ and $\mathrm{P}=10.3 \mathrm{mg} / \mathrm{L}$.

The contributions of the total absorbed minerals of the diet, including $\mathrm{Ca}, \mathrm{P}, \mathrm{Mg}$, K and $\mathrm{Na}$ are shown in Table 4. Daily deficiency was found in the contribution of $\mathrm{Mg}(-0.36 \mathrm{~g} /$ day $)$, $\mathrm{Na}(-25.2 \mathrm{~g} /$ day $)$ and $\mathrm{Ca}(-9.27 \mathrm{~g} /$ day). $\mathrm{K}(184.42 \mathrm{~g} /$ day $)$ and $\mathrm{P}(12.81 \mathrm{~g} /$ day $)$ were in excess, and the Ca:P ratio was 0.71 (Table 4).

From the results of the difference of the contributionrequirement the amounts of magnesium oxide $(\mathrm{MgO})$, calcium carbonate $\left(\mathrm{CaCO}_{3}\right)$ and sodium chloride $(\mathrm{NaCl})$ that would be necessary to add in the diet as sources of $\mathrm{Mg}$, $\mathrm{Ca}$ and $\mathrm{Na}$, respectively, were calculated to balance the deficiencies. The daily addition per cow of $80 \mathrm{~g}$ of $\mathrm{MgO}, 80 \mathrm{~g}^{\circ} \mathrm{CaCO}_{3}$ and $30 \mathrm{~g}$ of $\mathrm{NaCl}$ in the diet resolved the deficits of the respective minerals (Table 5).

Table 6 shows the balance of $\mathrm{Mg}$, $\mathrm{Ca}$ and Na minerals in the diet after making the respective corrections. The difference of

Table 1. Epidemiological data and blood serum levels of $\mathrm{Ca}, \mathrm{P}$ and Mg of lactating cows with clinical signs or clinically healthy cows

\begin{tabular}{|c|c|c|c|c|c|c|c|c|}
\hline $\begin{array}{c}\text { Ear tag } \\
\text { number }\end{array}$ & Age (years) & $\begin{array}{l}\text { Number of } \\
\text { lactations }\end{array}$ & Days in milk & $\begin{array}{l}\text { Production } \\
\text { average (L) }\end{array}$ & $\begin{array}{c}\text { Calcium } \\
(\mathrm{mmol} / \mathrm{L})\end{array}$ & $\begin{array}{l}\text { Phosphorus } \\
\text { (mmol/L) }\end{array}$ & $\begin{array}{c}\text { Magnesium } \\
(\mathrm{mmol} / \mathrm{L})\end{array}$ & Clinical signs \\
\hline 1131 & 9 & 6 & 48 & 26.8 & $0.81^{\mathrm{a}}$ & 1.85 & 0.5 & Yes \\
\hline 1715 & 6 & 5 & 194 & 29.2 & 0.92 & 0.83 & 0.94 & Yes \\
\hline 1314 & 5 & 4 & 69 & 31.2 & 1.89 & 1.84 & 0.37 & No \\
\hline 1912 & 2 & 1 & 112 & 15 & 2.18 & 1.77 & 0.42 & No \\
\hline 1950 & 4 & 2 & 107 & 30.2 & 2.22 & 1.82 & 0.94 & No \\
\hline 1959 & 2 & 1 & 112 & 21.4 & 2.35 & 2.08 & 0.71 & No \\
\hline 1972 & 2 & 1 & 112 & 15 & 2.07 & 1.29 & 0.88 & No \\
\hline 1990 & 2 & 1 & 118 & 18.6 & 2.22 & 1.52 & 0.68 & No \\
\hline 2000 & 2 & 1 & 123 & 17 & 2.37 & 1.57 & 0.88 & No \\
\hline \multicolumn{5}{|c|}{ Reference ranges (Constable et al. 2017) } & $2.1-2.6$ & $1.4-2.6$ & $0.7-1.2$ & \\
\hline
\end{tabular}

a The values in bold are below the reference range. 
Table 2. Ca, P, Mg and $\mathrm{K}$ values, tetanizing potential, and Ca:P ratio in the diet

\begin{tabular}{ccccccc}
\hline Diet component & $\mathrm{Ca}(\%)$ & $\mathrm{P}(\%)$ & $\mathrm{Mg}(\%)$ & $\mathrm{K}(\%)$ & $\mathrm{K} /(\mathrm{Ca}+\mathrm{Mg})$ ratio & Ca:P ratio \\
\hline Oat pasture A & 0.28 & 0.32 & 0.13 & 2.07 & 5.10 & 0.86 \\
Oat pasture B & 0.30 & 0.40 & 0.14 & 3.41 & 0.73 \\
Corn silage & 0.24 & 0.26 & 0.15 & 0.95 & 2.45 \\
Ration & 0.63 & 0.68 & 0.17 & 0.69 & 0.85
\end{tabular}

Table 3. Dry matter intake considering all components of the diet

\begin{tabular}{ccc}
\hline Diet component & \% in the diet (DM basis) & $\mathrm{kg} \mathrm{DM} /$ day \\
\hline Lush oat pasture & 64.51 & 12.62 \\
Corn silage & 19.82 & 3.88 \\
Ground corn grain & 8.00 & 1.57 \\
Barley grain & 3.63 & 0.71 \\
Soybean meal & 3.57 & 0.70 \\
Mineral supplement $^{\mathrm{a}}$ & 0.46 & 0.09 \\
Monensin $^{\mathrm{b}}$ & 0.01 & 0.0015
\end{tabular}

a Commercial formula reports: $9 \%$ of P, $18.8 \%$ of $\mathrm{Ca}, 1 \%$ of $\mathrm{Mg}, 12 \%$ of $\mathrm{Na}$ and $0 \% \mathrm{~K},{ }^{\mathrm{b}}$ commercial product with $20 \%$ monensin; DM $=$ dry matter.

Table 4. Difference of the contribution-requirement of minerals of the original diet

\begin{tabular}{|c|c|c|c|c|c|}
\hline & $\mathrm{Ca}$ & $\mathrm{P}$ & $\mathrm{Mg}$ & $\mathrm{K}$ & $\mathrm{Na}$ \\
\hline Total absorbed mineral requirements (TAM g/day) & 49.3 & 43.2 & 5.5 & 179.3 & 38.2 \\
\hline Gross diet contribution (g/day) & 81.6 & 83.9 & 29.4 & 403.3 & 14.4 \\
\hline Diet contribution (TAM g/day) & 38 & 56 & 4.7 & 362.9 & 13.0 \\
\hline Contribute water (TAM g/day) & 2.03 & 0.01 & 0.44 & 0.82 & \\
\hline Difference Contribution-Requirement (g/day) & $-9.27^{a}$ & 12.81 & -0.36 & 184.42 & -25.2 \\
\hline Ration density & 0.42 & 0.43 & 0.15 & 2.06 & 0.07 \\
\hline
\end{tabular}

a The values highlighted in bold are in excess or deficiency, the latter with the minus sign.

Table 5. Composition of the reformulated diet to correct $\mathrm{Mg}$, $\mathrm{Ca}$ and $\mathrm{Na}$ deficiencies

\begin{tabular}{ccc}
\hline Diet component & \%DM & Kg DM/day \\
\hline Lushreen oat pasture & 64.51 & 12.62 \\
Corn silage & 19.82 & 3.88 \\
Ground corn grain & 8.00 & 1.57 \\
Barley grain & 3.63 & 0.71 \\
Harina de soja & 3.57 & 0.70 \\
Mineral supplement & 0.46 & 0.09 \\
$\mathrm{MgO}$ & 0.40 & 0.08 \\
$\mathrm{CaCO}_{3}$ & 0.40 & 0.08 \\
$\mathrm{NaCl}$ & 0.15 & 0.03
\end{tabular}

Table 6. Difference of the contribution-requirement of minerals in the reformulated diet

\begin{tabular}{cccccc}
\hline & $\mathrm{Ca}$ & $\mathrm{P}$ & $\mathrm{Mg}$ & $\mathrm{K}$ & $\mathrm{Na}$ \\
\hline Total absorbed mineral requirements (TAM g/day) & 49.3 & 43.2 & 5.5 & 379.3 & 403.3 \\
Gross diet contribution (g/day) & 95.7 & 83.9 & 74.4 & 36.2 \\
Diet contribution (TAM g/day) & 47.5 & 56 & 36.2 & 41.3 \\
Contribute water (TAM g/day) & 2.03 & 0.01 & 0.44 & 0.82 & 184.52 \\
Difference contribution-requirement (g/day) & $\mathbf{0 . 2 3}^{\mathrm{a}}$ & 12.81 & $\mathbf{3 1 . 1 4}$ & $\mathbf{3 . 1 0}$ & 0.23 \\
Ration density & 0.48 & 0.42 & 0.38 & 2.04
\end{tabular}

$\overline{\mathrm{a}}$ The values of $\mathrm{Mg}$, Ca and $\mathrm{Na}$ minerals in bold were corrected.

the contribution-requirement is adequate for $\mathrm{Ca}(0.23 \mathrm{~g} / \mathrm{day})$, $\mathrm{Mg}(0.31 \mathrm{~g} /$ day) and $\mathrm{Na}(3.1 \mathrm{~g} /$ day). The Ca:P ratio increased to 0.88 .

At necropsy, both carcasses were in acceptable body condition score (3.5 on a scale of 1 to 5), with adequate fat reserves and moderate sinking of the eyes in the orbit (dehydration). In $80 \%$ of the endocardial surface, ecchymosis and suffusions were observed. In the epicardium as well as the subcutaneous tissue, there were multiple petechiae. The urinary bladder was moderately distended with dark amber urine. No remarkable lesions were observed in other organs.

Microscopically, the epicardial and endocardial hemorrhages observed at necropsy were confirmed and the cardiac muscle 
revealed acute mild multifocal hydropic degeneration. There were no lesions of diagnostic importance in the other tissues examined. No pathogenic bacteria were isolated from lung, kidney, liver and CSF.

\section{DISCUSSION}

The diagnosis of hypomagnesemia in the outbreak described herein was based on epidemiological and clinical findings and confirmed by determination of low serum $\mathrm{Mg}$ values and by the analysis of the diet, which showed low concentrations of $\mathrm{Mg}$ and $\mathrm{Na}$, high values of $\mathrm{K}$ and $\mathrm{P}$, and a $\mathrm{K} /(\mathrm{Ca}+\mathrm{Mg})$ ratio higher than 2.2. Serum $\mathrm{Mg}$ values within the normal range in one of the clinically ill cows can be explained by the treatment with a calcium and magnesium solution before death (Goff 1999, Martín-Tereso \& Martens 2014).

Subclinical hypomagnesemia, with $\mathrm{Mg}$ values between 0.41-0.82 (Constable et al. 2017) or 0.7-0.8mmol/L (Martens et al. 2018) and clinical hypomagnesemia with values on average of $0.21 \mathrm{mmol} / \mathrm{L}$ (Constable et al. 2017) have primary and secondary causes. The primary cause is the deficit in dietary Mg supply (Ram et al. 1998). Secondary hypomagnesemia might be triggered by high values of $\mathrm{K}$, protein or non-protein $\mathrm{N}$ and low concentration of soluble carbohydrates (Bohman et al. 1983). In the current report, the estimated difference in dietary mineral contribution-requirement shows that the intake of $\mathrm{Mg}$, $\mathrm{Ca}$ and $\mathrm{Na}$ were deficient according to the requirements (NRC 2001). The cows were fed lush oat pasture and corn silage, both deficient in $\mathrm{Mg}$, which may have contributed to a primary Mg deficit. On the other hand, K values were high in both lush oat pastures and in corn silage, which probably contributed secondarily to the occurrence of the disease. The $\mathrm{K} /(\mathrm{Ca}+\mathrm{Mg})$ ratio higher than 2.2 found in this work is an indicator of the tetanizing potential of forages (Kemp \& t'Hart 1957). The diet that was consuming the herd had low concentrations of $\mathrm{Mg}$ and high values of $\mathrm{K}$, what suggests that the absorption of the Mg may have been drastically diminished (Schonewille et al. 2008). P was elevated in the diet, which also interferes with Mg absorption (Reinhardt et al. 1988). In addition, the $\mathrm{Na}$ was below the recommended percentage for the species (NRC 2001). The low supply of $\mathrm{Na}$ in the diet reduces the absorption of $\mathrm{Mg}$ in the rumen (Goff 2014) by decreasing the active transport of Mg bound to $\mathrm{Na}$ (Martens et al. 1987). Other factors that contribute to secondary hypomagnesemia, which were not evaluated in this outbreak, are the high levels of protein and non-protein $\mathrm{N}$ that occur in the lush winter forages. The green oat forages have high values of protein (6.9-30.8\%) (Pordomingo et al. 2007 ) and $N(1.86-2.32 \%)$ (Flores et al. 2014) that favor the formation of ammonium and ammonia ions that interfere with Mgabsorption (Care et al. 1984). Green oat forages also have low values of soluble carbohydrates (5.7\% to $16.8 \%$ ) (Pordomingo et al. 2007) which reduces the active transport of Mg (Martens 1985).

The epidemiological data of the outbreak indicate that several risk factors may have predisposed to hypomagnesemia. The herd consisted of high-producing lactating cows, which excrete around $116 \mathrm{mg} / \mathrm{L}$ daily of Mg (Van Hulzen et al. 2009). Some of the deceased cows were within the oldest of the herd, from 6 to 9 years-old, age at which the absorption capacity of dietary Mg decreases (Van Mosel et al. 1991). In addition, the outbreak occurred in autumn and the beginning of winter, the time of greatest risk for elevated tetanizing potential of the fast growing winter forages, and probably by stressing climate changes such as intense cold, rain and cloudy days (Larvor 1976, Brizuela \& Cseh 2003).

The blood Ca values in the clinically-affected and some of the healthy cows were below the normal range $(2.1-2.6 \mathrm{mmol} / \mathrm{L})$ (Constable et al. 2017) but none had clinical hypocalcemia that occurs with values lower than 1.38mmol/L (Goff 2014). Sudden death, the acute neurological clinical manifestation in this outbreak, and the stage of lactation of the affected cows were not consistent with those of puerperal hypocalcemia. Most likely subclinical hypocalcemia in these cows was a consequence of hypomagnesemia, as previously reported (Van Mosel et al. 1991). Even though the Ca:P ratio was suboptimal, it has been shown that in the presence of low $\mathrm{Mg}$ values the production of parathormone and the sensitivity of bone cells to this hormone are reduced, leading to hypocalcemia (Fatemi et al. 1991, Kopic \& Geibel 2013). In this outbreak, acute clinical signs and death occurred primarily due to hypomagnesemia, confirmed by serum Mg concentrations lower than $0.5 \mathrm{mmol} / \mathrm{L}$, as that found in experimental hypomagnesemia (McCoy et al. 2001).

Hypomagnesemia occurs frequently in New Zealand (Metson et al. 1966), Australia (Harris et al. 1983), Canada (Odette 2005) and Argentina (Cseh \& Crenovich 1996, Cantón et al. 2014). In New Zealand, the intensification of grazing livestock improves milk production per cow, per hectare, and profitability, but requires greater forage production, which is achieved by applying fertilizers such as $\mathrm{N}$ and $\mathrm{K}$ (Macdonald et al. 2017). The increase of $\mathrm{N}$ and $\mathrm{K}$ in the soil is reflected in the forages and decreases the absorption and availability of $\mathrm{Mg}$ for the animals (Metson et al. 1966, Elliott 2008). Thus, supplementation with Mg is necessary to prevent hypomagnesemia (Goff 2006, Zelal 2017, Martens et al. 2018). In Uruguay, hypomagnesemia has been described in recently weaned beef cows locked in pens for long periods without access to water or food (Dutra 2009, 2010). We do not find publications on hypomagnesemia in dairy cattle in Uruguay, but it is possible that the disease is underdiagnosed. In recent years dairy farming in Uruguay has undergone a process of intensification (Inale 2014, Uruguay 2016), local dairy farmers and veterinary practitioners alike should be aware of the risk of hypomagnesemia in high-producing grazing dairy systems.

The recommendation to correct the dietary deficiencies of $\mathrm{Mg}, \mathrm{Ca}$ and $\mathrm{Na}$ was based on the detected values of such minerals in the diet. The lush oat pastures used as the basis of the diet in the current outbreak were deficient in $\mathrm{Mg}$, rich in $\mathrm{K}$, the Ca:P ratio was lower than 1 and had also low levels of $\mathrm{Na}$. The forages of autumn-winter lush growth contribute between $0.14 \%$ and $0.19 \% \mathrm{Mg}$ in DM (Metson et al. 1966, Brizuela \& Cseh 2003, Blackwood 2007), considering that $\mathrm{K}$ values were greater than $1 \%$, it is recommended that $0.35 \% \mathrm{Mg}$ be supplied in the total ration on DM basis (Schonewille et al. 2008, Martín-Tereso \& Martens 2014). A cow that produces $20 \mathrm{~L}$ of milk daily requires $70 \mathrm{~g}$ of $\mathrm{Mg}$ daily (NRC 2001). The diet and water that the cows were consuming in this outbreak contributed approximately $30 \mathrm{~g}$ of $\mathrm{Mg}$ per cow daily, so $40 \mathrm{~g}$ of $\mathrm{Mg}$ were deficient and had to be supplemented in the reformulated diet. From 65 to $75 \mathrm{~g}$ of $\mathrm{MgO}$ per cow daily as source of $\mathrm{Mg}$ was provided to correct the deficiency (Urdaz et al. 2003). 
The occurrence of an outbreak of hypomagnesemia in a dairy farm that applies similar technology to many other dairy farms in Uruguay suggests that nutritional practices should be recommended for the prevention of this disease in the country. To administer the $\mathrm{MgO}$ preparing a ration that includes the amounts mentioned above is suggested. Another strategy is to supplement part of the $\mathrm{MgO}$ in the ration and the remaining in the mineral salt. In this case, $45 \mathrm{~g}$ of $\mathrm{MgO}$ should be mixed in the ration and a mixture of $75 \% \mathrm{NaCl}$ and $25 \% \mathrm{MgO}$ should be offered at libitum concomitantly. This improves palatability and provides a source of $\mathrm{Na}$. When $\mathrm{Mg}$ is added to the diet or salt, the DM and mineral salt intake should be monitored since MgO lacks palatability (Zelal 2017). The deficiency of $\mathrm{Na}$ can be corrected by adding $0.5 \% \mathrm{NaCl}$ and the Ca:P ratio is improved by adding 1 to $1.5 \% \mathrm{CaCO}_{3}$ to the ration on DM basis, especially when commercial pellets with grains or by-products are used (corn, sorghum, bran of wheat or rice, soybean flour or expeller, corn lex) instead of balanced ration. Finally, it is recommended that each farm owner evaluates the situation of dietary contributions and requirements of cattle in production.

\section{CONCLUSIONS}

Hypomagnesemia is a cause of mortality in lactating dairy cattle in Uruguay and should be included in the differential diagnosis of acute neurological clinical signs and/or sudden death.

The risk for hypomagnesemia is increased when the base of the diet are lush grasses of fast autumn and winter growth, with low $\mathrm{Mg}$ and high $\mathrm{K}$ levels.

Hypomagnesemia can be prevented by an appropriate diet formulation.

Acknowledgements.- We thank Dr. Gonzalo Uriarte from the Division of Veterinary Laboratories (División de Laboratorios Veterinarios) (DILAVE) and Andrés Beretta from INIA's Soil Plant and Water Laboratories (Laboratorio de Suelos, Plantas y Agua) for biochemical testing on various samples, and Dr. Martin Karlen for providing clinical and epidemiological data. We also thank Yisell Perdomo from INIA for assistance with histologic techniques.

Conflict of interest statement.- The authors have no competing interests.

\section{REFERENCES}

Alfrey A.C. \& Miller N.L. 1973. Bone magnesium pools in uremia. J. Clin. Invest. 52(12):3019-3027. <http://dx.doi.org/10.1172/JCI107500> <PMid:4584344>

Allcroft R. \& Burns K.N. 1968. Hypomagnesaemia in cattle. N.Z. Vet. J. 16(7):109-128. <http://dx.doi.org/10.1080/00480169.1968.33757> $<$ PMid:4884842>

Alharthi A., Zhou Z., Lopreiato E., Trevisi E. \& Loor J.L. 2018. Body condition score prior to parturition is associated with plasma and adipose tissue biomarkers of lipid metabolism and inflammation in Holstein cows. J. Anim. Sci. Biotechnol. 9(1):1-12. <http://dx.doi.org/10.1186/s40104017-0221-1><PMid:29387386>

Baginski E.S., Epstein E. \& Zak B. 1975. Review of phosphate methodologies. Ann. Clin. Lab. Sci. 5(5):399-416. <PMid:1180482>

Bazydlo L.A.L., Needham M. \& Harris N.S. 2014. Calcium, magnesium, and phosphate. Lab. Med. 45(1):e44-e50. <http://dx.doi.org/10.1309/ LMGLMZ8CIYMFNOGX>
Blackwood I. 2007. Mineral content of common ruminant stockfeeds, crops and pastures. Primefact 522, NSW Department of Primary Industries. Orange $7 \mathrm{p}$.

Bohman V.R., Horn F.P., Stewart B.A., Mathers A.C. \& Grunes D.L. 1983. Wheat pasture poisoning. I. An evaluation of cereal pastures as related to tetany in beef cows. J. Anim. Sci. 57(6):1352-1363.<http://dx.doi.org/10.2527/ jas1983.5761352x > <PMid:6674278>

Brizuela M.A. \& Cseh S.B. 2003. Composición mineral y potencial tetanizante de verdeos de invierno sembrados en diferentes fechas. Revta Arg. Prod. Anim. 23(2):91-101.

Cajarville C., Britos A., Errandonea N., Gutiérrez L., Cozzolino D. \& Repetto J.L. 2015. Diurnal changes in water-soluble carbohydrate concentration in lucerne and tall fescue in autumn and the effects on in vitro fermentation. N. Z. J. Agricult. Res. 58(3):281-291. <http://dx.doi.org/10.1080/00288 233.2015.1018391>

Cantón G., Odriozola E. \& Cseh S. 2014. Análisis de casos de hipomagnesemia en bovinos de producción de carne diagnosticados en INTA EEA Balcarce (1998-2013).XX Reunión Científica Técnica, Tucumán, Argentina. (Resumen)

Care A.D., Brown R.C., Farrar A.R. \& Pickard D.W. 1984. Magnesium absorption from the digestive tract of sheep. Q. J. Exp. Physiol. 69(3):577-587.<http:// dx.doi.org/10.1113/expphysiol.1984.sp002844><PMid:6473696>

Cerbulis J. \& Farrell Junior J. 1976. Composition of the milk of dairy cows. II. Ash, calcium, magnesium, and phosphorous. J. Dairy Sci. 59(4):589-593. <http://dx.doi.org/10.3168/jds.S0022-0302(76)84245-2><PMid:1262573>

Chatterton N.J., Harrison P.A., Bennett J.H. \& Asay K.H. 1989. Carbohydrate partitioning in 185 accessions of Gramineae grown under warm and cool temperatures. J. Plant Physiol. 134(2):169-179. <http://dx.doi.org/10.1016/ S0176-1617(89)80051-3>

Chatterton N.J., Watts K.A., Jensen K.B., Harrison P.A. \& Horton W.H. 2006. Nonstructural carbohydrates in oat forage. J. Nutr. 136(Suppl.7):2111S2113S. <http://dx.doi.org/10.1093/jn/136.7.2111S><PMid:16772513>

Constable P.D., Hinchcliff K.W., Done S.H. \& Grünberg W. 2017. Veterinary Medicine. 11th ed. Saunders Elsevier, St Louis, Missouri, p.1662-1706.

Contreras G.A., Thelen K., Schmidt S.E., Strieder-Barboza C., Preseault C.L., Raphael W., Kiupel M., Caron J. \& Lock A.L. 2016. Adipose tissue remodeling in late-lactation dairy cows during feed restriction-induced negative energy balance. J. Dairy Sci. 99(12):1-13. <http://dx.doi.org/10.3168/ jds.2016-11552><PMid:27720147>

Cook G.M., Wells J.E. \& Russell J.B. 1994. Ability of Acidaminococcus fermentans to oxidize trans-aconitate and decrease the accumulation of tricarballylate, a toxic end product of ruminal fermentation. Appl. Environ. Microbiol. 60(7):2533-2537. <PMid:8074529>

Crawford R.J., Masie M.D., Sleper D.A. \& Mayland H.F. 1998. Use of an experimental high-magnesium tall fescue to reduce grass tetany in cattle. J. Prod. Agricult. 11(4):491-496. <http://dx.doi.org/10.2134/jpa1998.0491>

Cseh S.B. \& Crenovich H. 1996. Hipomagnesemia en el sudeste de la provincia de Buenos Aires, Argentina. Arch. Med. Vet. 28(2):111-116.

D’Angelo A., Bellino C., Bertone I., Cagnotti G., Iulini B., Miniscalco B., Casalone C., Gianella P. \& Cagnasso A. 2015. Seizure disorders in 43 cattle. J. Vet. Intern. Med. 29(3):967-971. <http://dx.doi.org/10.1111/jvim.12592> <PMid:25857732>

Dutra F. 2009. Tetania del transporte. Arch. Vet. Este Ururguay 2:6-7.

Dutra F. 2010. Tetania del destete. Arch. Vet. Este Ururguay 2:10-11.

Elliott D.A. \& Rizack M.A. 1974. Epinephrine and adrenocorticotropic hormone-stimulated magnesium accumulation in adipocytes and their plasma membranes. J. Biol. Chem. 249(12):3985-3990. <PMid:4365743>

Elliott M. 2008. Grass tetany in cattle: predicting its likelihood. Primefact 785. NSW Department of Primary Industries, Orange. 6p. 
Elliott M. 2009. Grass tetany in cattle: treatment and prevention. Primefact 421. NSW Department of Primary Industries, Orange. 4p.

Fatemi S., Ryzen E., Flores J., Endres D.B. \& Rude R.K. 1991. Effect of experimental human magnesium depletion on parathyroid hormone secretion and 1.25-dihydroxyvitamin D metabolism. J. Clin. Endocrinol. Metabol. 73(5):1067-1072.<http://dx.doi.org/10.1210/jcem-73-5-1067> <PMid:1939521>

Fisher L.J., Dinn N., Tait R.M. \& Shelford J.A. 1994. Effect of level of dietary potassium on the absorption and excretion of calcium and magnesium by lactating cows. Can. J. Anim. Sci. 74(3):503-509. <http://dx.doi. org/10.4141/cjas94-071>

Flores F.E., Casillas H.M., Figueroa U.V. \& Potisek M.C.T. 2014. Disponibilidad de nitrógeno y desarrollo de avena forrajera (avena sativa l.) con aplicación de biosólidos. Revta Terra Latinoamericana 32:99-105.

Fox R.H. \& Piekielek W.P. 1984. Soil magnesium level, corn (Zea mays L.) yield, and magnesium uptake. Commun. Soil Sci. Plan. 15(2):109-123. <http:// dx.doi.org/10.1080/00103628409367459>

Gabel G. \& Martens H. 1986. The effect of ammonia on magnesium metabolism in sheep. J. Anim. Physiol. Anim. Nutr., Berlin 55(1/5):278-287. <http:// dx.doi.org/10.1111/j.1439-0396.1986.tb00729.x>

Giduck S.A. \& Fontenot J.P. 1987. Utilization of magnesium and other macrominerals in sheep supplemented with different readily-fermentable carbohydrates. J. Anim. Sci. 65(6):1667-1673. <http://dx.doi.org/10.2527/ jas1987.6561667x > <PMid:3443586>

Goff J.P. 1999. Treatment of calcium, phosphorus, and magnesium balance disorders. Vet. Clin. N. Am., Food Anim. Pract. 15(3):619-639. <http:// dx.doi.org/10.1016/S0749-0720(15)30167-5> <PMid:10573815>

Goff J.P. 2006. Macromineral physiology and application to the feeding of the dairy cow for prevention of milk fever and other periparturient mineral disorders. Anim. Feed Sci. Technol. 126(3/4):237-257. <http://dx.doi. $\operatorname{org} / 10.1016 /$ j.anifeedsci.2005.08.005>

Goff J.P. 2008. The monitoring, prevention, and treatment of milk fever and subclinical hypocalcemia in dairy cows. Vet. J. 176(1):50-57. <http:// dx.doi.org/10.1016/j.tvjl.2007.12.020 > <PMid:18342555>

Goff J.P. 2014. Calcium and magnesium disorders. Vet. Clin. N. Am., Food Anim. Pract. 30(2):359-381, vi. <http://dx.doi.org/10.1016/j.cvfa.2014.04.003> $<$ PMid:24980727>

Grunes D.L., Stout P.R. \& Brownell J.R. 1970. Grass tetany of ruminants. Adv. Agron. 22:331-374. <http://dx.doi.org/10.1016/S0065-2113(08)60272-2>

Harris D.J., Lambell R.G. \& Oliver C.J. 1983. Factors predisposing dairy and beef cows to grass tetany. Aust. Vet. J. 60(8):230-234. <http://dx.doi. org/10.1111/j.1751-0813.1983.tb05970.x><PMid:6639526>

House W.A. \& Bell A.W. 1993. Mineral accretion in the fetus and adnexa during late gestation in Holstein cows. J. Dairy Sci. 76(10):2999-3010. <http:// dx.doi.org/10.3168/jds.S0022-0302(93)77639-0><PMid:8227626>

Inale 2014. Encuesta lechera. Instituto Nacional de la Leche, Montevideo. Available at <https://www.inale.org/historico/wp-content/uploads/2018/08/ Encuesta-lechera-2014.pdf> Accessed on Jun. 3, 2018.

INIA. Laboratorio de Suelos, Plantas y Aguas. 2017. Plantas y Aguas. Carpeta de técnicas oficiales. La Estanzuela, Uruguay.

Jackson M.L. 1964. Análisis Químico de Suelos. Ed. Omega, Barcelona. 662p.

Jones E. 1963. Studies on the magnesium content of mixed herbage and some individual grass and clover species. J. Brit. Grassl. Soc. 18(2):131-138.

Kemp A. \& t'Hart M.L. 1957. Grass tetany in grazing milking cows. Neth. J. Agric. Sci. 5:4-17.

Kemp A., Deys W.B., Hemkes O.J. \& Vann Es A.J.H. 1961. Hypomagnesaemia in milking cows: intake and utilization of magnesium from herbage by lactating cows. Neth. J. Agric. Sci. 9(2):134-149.
Kopic S. \& Geibel J.P. 2013. Gastric acid, calcium absorption, and their impact on bone health. Physiol. Rev. 93(1):189-268. <http://dx.doi.org/10.1152/ physrev.00015.2012><PMid:23303909>

Larvor P. 1976. 28Mg kinetics in ewes fed normal or tetany prone grass Cornell Vet. 66(3):413-429. <PMid:954445>

Li F.Y., Chaigne-Delalande B., Kanellopoulou C., Davis J.C., Matthews H.F., Douek D.C., Cohen J.I., Uzel G., Su H.C. \& Lenardo M.J. 2011. Second messenger role for $\mathrm{Mg} 2+$ revealed by human T-cell immunodeficiency. Nature 475(7357):471-476. <http://dx.doi.org/10.1038/nature10246> <PMid:21796205>

MacDonald K.A., Penno J.W., Lancaster J.A.S., Bryant A.M., Kidd J.M. \& Roche J.R. 2017. Production and economic responses to intensification of pasturebased dairy production systems. J. Dairy Sci. 100(8):6602-6619. <http:// dx.doi.org/10.3168/jds.2016-12497> <PMid:28601460>

Martens H. 1985. The effect of dinitrophenol on magnesium transport across an isolated preparation of sheep rumen epithelium. Q. J. Exp. Physiol. 70(4):567-573. <http://dx.doi.org/10.1113/expphysiol.1985.sp002943> $<$ PMid:3001811>

Martens H. \& Blume I. 1986. Effect of intraruminal sodium and potassium concentrations and of the transmural potential difference on magnesium absorption from the temporarily isolated rumen of sheep. Q. J. Exp. Physiol. 71(3):409-415.<http://dx.doi.org/10.1113/expphysiol.1986.sp002999> $<$ PMid:3763804>

Martens H. \& Schweigel M. 2000. Pathophysiology of grass tetany and other hypomagnesemias. Implications for clinical management. Vet. Clin. N. Am., Food Anim. Pract. 16(2):339-368. <http://dx.doi.org/10.1016/S07490720(15)30109-2><PMid:11022344>

Martens H., Kubel O.W., Gäbel G. \& Honi H. 1987. Effects of low sodium intake on magnesium metabolism in sheep. J. Agric. Sci. 108(1):237-243. <http:// dx.doi.org/10.1017/S0021859600064315>

Martens H., Leonhard-Marek S., Röntgen M. \& Stumpff F. 2018. Magnesium homeostasis in cattle: absorption and excretion. Nutr. Res. Rev. 31(1):1-17. <http://dx.doi.org/10.1017/S0954422417000257><PMid:29318981>

Martín-Tereso J. \& Martens H. 2014. Calcium and magnesium physiology and nutrition in relation to the prevention of milk fever and tetany (dietary management of macrominerals in preventing disease). Vet. Clin N. Am., Food Anim. Pract. 30(3):643-670. <http://dx.doi.org/10.1016/j. cvfa.2014.07.007> <PMid:25245611>

Maylan H.F., Grunes D.L. \& Lazar V.A. 1976. Grass tetany hazard of cereal forages based upon chemical composition. Agron. J. 68(4):665-667. <http:// dx.doi.org/10.2134/agronj1976.00021962006800040033x>

McCoy M.A., Hutchinson T., Davison G., Fitzpatrick D.A., Rice D.A. \& Kennedy D.G. 2001. Postmortem biochemical markers of experimentally induced hypomagnesaemic tetany in cattle. Vet. Rec. 148(9):268-273. <http:// dx.doi.org/10.1136/vr.148.9.268> <PMid:11292087>

McCoy M.A. 2004. Hypomagnesemia and new data on vitreous humor magnesium concentration as a post-mortem marker in ruminants. Magnes Res. 17(2):137-145. <PMid:15319147>

Metson A.J., Saunders W.M.H., Collie T.W. \& Graham V.W. 1966. Chemical composition of pastures in relation to grass tetany in beef breeding cows. N.Z. J. Agric. Res. 9(2):410-436. <http://dx.doi.org/10.1080/00288233. 1966.10420793>

Meyer H. 1977. Pathogenesis of the clinical symptoms of hypomagnesaemia in ruminants. Vet. Sci. Commun. 1(1):43-50. <http://dx.doi.org/10.1007/ BF02267632>

Möykkynen T., Uusi-Oukari M., Heikkila J., Lovinger D.M., Lüddens H. \& Korpi E.R. 2001. Magnesium potentiation of the function of native and recombinant GABA (A) receptors. Neuroreport 12(10):2175-2179. <http:// dx.doi.org/10.1097/00001756-200107200-00026> <PMid:11447329> 
Muller L.D. 2003. Supplementation of lactating cows on pastures. Available at <https://extension.psu.edu/supplementation-of-lactating-cows-onpasture> Accessed on Jun. 3, 2018.

Naik S.G., Ananda K.J. \& Rani B.K. 2010. Magnesium deficiency in young calves and its management. Vet. World 3(4):192-193.

NRC 2001. Nutrient Requirements of Dairy Cattle. 7th ed. National Academy Press, Washington, DC. 405p.

Odette 0. 2005. Grass tetany in a herd of beef cows. Can. Vet. J. 46(8):732734. <PMid:16187719>

Pordomingo A.J., Quiroga A., Jonas O., Santucho G., Otamendi H., Buffa H.G., Rolheiser D.0. \& Albertario P. 2007. Producción y valor nutritivo de verdeos de invierno en siembra directa. Available at <https://www.engormix.com/ ganaderia-carne/articulos/valor-nutritivo-verdeos-invierno-siembradirecta-t27006.htm> Accessed on Aug. 20, 2018.

Ram L., Schonewille J.T., Martens H., Van't Klooster A.T. \& Beynen A.C. 1998. Magnesium absorption by wethers fed potassium bicarbonate in combination with different dietary magnesium concentrations. J. Dairy Sci. 81(9):2485-2492. <http://dx.doi.org/10.3168/jds.S0022-0302(98)701407><PMid:9785240>

Rayssiguier Y. 1977. Hypomagnesemia resulting from adrenaline infusion in ewes: its relation to lipolysis. Horm. Metab. Res. 9(4):309-314. <http:// dx.doi.org/10.1055/s-0028-1093519><PMid:892696>

Rayssiguier Y. \& Larvor P. 1978. Mineral bone composition and some elements of calcium metabolism in magnesium-deficient growing rats. Ann. Biol. Anim. Bioch. Biophys. 18(1):157-166. <http://dx.doi.org/10.1051/ rnd:19780120>

Reinhardt T.A., Lippolis J.D., McCluskey B.J., Goff J.P. \& Horst R.L. 2011. Prevalence of subclinical hypocalcemia in dairy herds. Vet. J. 188(1):122124. <http://dx.doi.org/10.1016/j.tvjl.2010.03.025><PMid:20434377>

Reinhardt T.A., Horst R.L. \& Goff J.P. 1988. Calcium, phosphorus, and magnesium homeostasis in ruminants. Vet. Clin. N. Am., Food Anim. Pract. 4(2):331-350. <http://dx.doi.org/10.1016/S0749-0720(15)31052-5><PMid:3061612>

Rérat M., Philipp A., Hess H.D. \& Liesegang A. 2009. Effect of different potassium levels in hay on acid-base status and mineral balance in periparturient dairy cows. J. Dairy Sci. 92(12):6123-6133. <http://dx.doi.org/10.3168/ jds.2009-2449><PMid:19923615>

Rude R.K. 1998. Magnesium deficiency: a cause of heterogeneous disease in humans. J. Bone Miner. Res. 13(4):749-758. <http://dx.doi.org/10.1359/ jbmr.1998.13.4.749><PMid:9556074>

Sánchez J.M. 2000. Hipomagnesemia. Un desbalance metabólico subestimado en la producción de ganado lechero en Costa Rica. Nut. Anim. Trop. 6(1):75-95.

Schonewille J., Everts H., Jittakhot S. \& Beynen A.C. 2008. Quantitative prediction of magnesium absorption in dairy cows. J. Dairy Sci. 91(1):271278. <http://dx.doi.org/10.3168/jds.2007-0304><PMid:18096949>
Smith R.A. \& Edwards W.C. 1988. Hypomagnesemic tetany of ruminants. Vet. Clin. N. Am., Food Anim. Pract. 4(2):365-377. <http://dx.doi.org/10.1016/ S0749-0720(15)31054-9><PMid:3061613>

Storry J.E. \& Rook J.A.F. 1962. The magnesium nutrition of the dairy cow in relation to the development of hypomagnesaemia in the grazing animal. J. Sci. Food Agric. 13(12):621-627. <http://dx.doi.org/10.1002/ jsfa.2740131201>

Tsiamadis V., Banos G., Panousis N., Kritsepi-Konstantinou M., Arsenos G. \& Valergakis G.E. 2016. Genetic parameters of subclinical macromineral disorders and major clinical diseases in postparturient Holstein cows. J. Dairy Sci. 99(11):1-14. <http://dx.doi.org/10.3168/jds.2015-10789> $<$ PMid:27614830>

Urdaz J.H., Santos J.E., Jardon P. \& Overton M.W. 2003. Importance of appropriate amounts of magnesium in rations for dairy cows. J. Am. Vet. Med. Assoc. 222(11):1518-1523. <http://dx.doi.org/10.2460/javma.2003.222.1518> $<$ PMid:12784955>

Van Hulzen K.J., Sprong R.C., van der Meer R. \& van Arendonk J.A. 2009. Genetic and nongenetic variation in concentration of selenium, calcium, potassium, zinc, magnesium, and phosphorus in milk of Dutch HolsteinFriesian cows. J. Dairy Sci. 92(11):5754-5759. <http://dx.doi.org/10.3168/ jds.2009-2406><PMid:19841235>

Van Mosel M., Van't Klooster A.T. \& Wouterse H.S. 1991. Effects of a deficient magnesium supply during the dry period on bone turnover of dairy cows at parturition. Vet. Q. 13(4):199-208. <http://dx.doi.org/10.1080/01652 176.1991.9694309><PMid:1776234>

Van Netten P., Perales I., van de Moosdijk A., Curtis G.D. \& Mossel D.A. 1989. Liquid and solid selective differential media for the detection and enumeration of L. monocytogenes and other Listeria spp. Int. J. Food Microbiol. 8(4):299-317. <http://dx.doi.org/10.1016/0168-1605(89)90001-9><PMid:2518321>

Uruguay 2016. Estadística de la producción lechera 2016. Dirección de Estadísticas Agropecuarias, Ministerio de Ganadería, Agricultura y Pesca, Montevideo. Available at <http://www.mgap.gub.uy/unidad-organizativa/ oficina-de-programacion-y-politicas-agropecuarias/publicaciones/ anuarios-diea/anuario2016> Accessed on Jun. 3, 2018.

Watson E.N., David G.P. \& Cook A.J.C. 2008. Review of diagnostic laboratory submissions of adult cattle 'found dead' in England and Wales in 2004. Vet. Rec. 163(18):531-535. <http://dx.doi.org/10.1136/vr.163.18.531> <PMid:18978365>

Zelal A. 2017. Hypomagnesemia tetany in cattle. J. Adv. Dairy Res. 5(2):1-9. <http://dx.doi.org/10.4172/2329-888X.1000178>

Zheng J., Mao X., Ling J., Chen C. \& Zhang W. 2016. Role of magnesium transporter subtype 1 (MagT1) in the osteogenic differentiation of rat bone marrow stem cells. Biol. Trace Elem. Res. 171(1):131-137. <http:// dx.doi.org/10.1007/s12011-015-0459-4><PMid:26358767> 